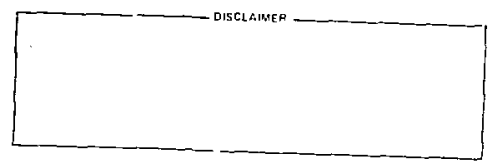

\title{
Permeability of Stemming Materials for Prompt Gas Sampling
}

\author{
J. Beiriger \\ D. Trimmer
}

Manuscript Date: January 1982

LAWRENCE LIVERMORE LABORATORY Lniversity of California - Livermore. Catitomia 94550 


\title{
Permeability of Stemming Materials for Prompt Gas Sampling
}

\begin{abstract}

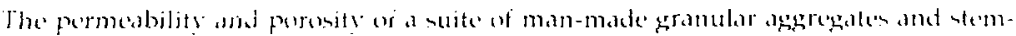

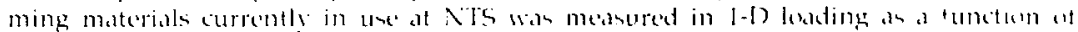

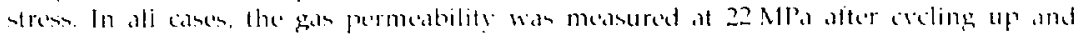

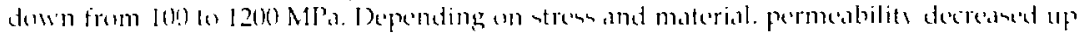

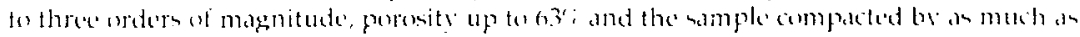

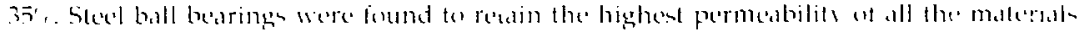

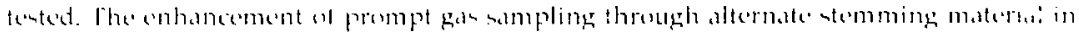

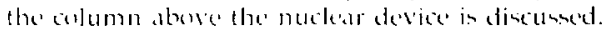

\section{Intrcduction}

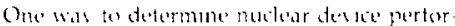
mance after underground mulear ditumatione in

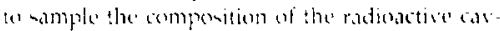

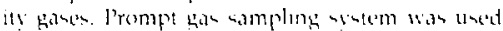
a) recower samplese soun after detentation. The downhole portion of this watene in primarily a howe put in before stemming (tilling) the emplacement hole. The home end abere the anticipated casts: Gas from the adste must flus to the hose through stemming material crmpated by the detorations.

Optimal ue of semming malerial and sampling hose plarement requires hmoneledge of the it $\rightarrow$ in strens field and the resultiag changes in stemming mateidal permeabilits and poressty im. modiately after a detonation. The determination

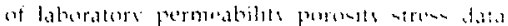

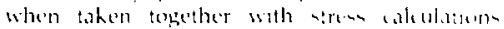

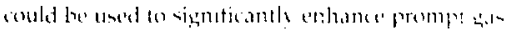
nompling - ucosess.

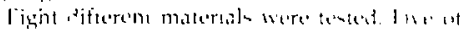

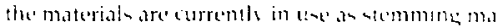

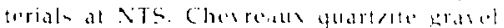

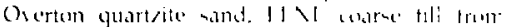

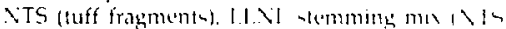

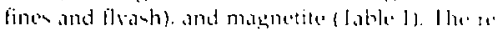

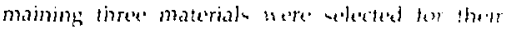

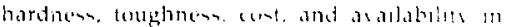
quantities appropriate for prompt gas somplone. These three malerials sere mpure alumuna (firid! baxited, pum alt: aina balls, and serel bol! bearings

Table 1. Tested materials.

\begin{tabular}{|c|c|c|c|}
\hline Vaterial & $\begin{array}{c}\text { Specification No. } \\
\text { dencription }\end{array}$ & bizk & 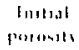 \\
\hline Cherresus quartite gravel & 111 $=9-001+4 h-1$ & $2.3 \mathrm{n} 1112.5 \mathrm{~mm}$ & $11.4 ;$ \\
\hline $1 I \backslash I$ conarse till & $111-7 h-1001+1111-x$ & 2 to $12.5 \mathrm{~mm}$ & if 14 \\
\hline 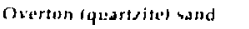 & $111176-0012421$ & 75 मा11 $102 \mathrm{~mm}$ & 11. $3=$ \\
\hline 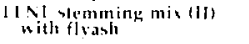 & $314775-001282-4$ & $15 \mathrm{ta} 12.5 \mathrm{~mm}$ & 0.31 \\
\hline Magnetite & S111 in.0013001-A & 1 ก0 $\mu \mathrm{m} 10+. .2 \mathrm{~mm}$ & 0.31 \\
\hline Alumina, impure & $\begin{array}{l}\text { P'orrus, irregular } \\
\text { hhaped balds }\end{array}$ & $5.08 \mathrm{t} n \mathrm{n} .75 \mathrm{~mm}$ & $11+3$ \\
\hline Nlumins, pure & $\begin{array}{l}\text { Spheres } \\
\text { r3.4 specific } \\
\text { hravifyl }\end{array}$ & $6.35 \mathrm{~mm}$ & 11.44 \\
\hline steel ball boaringh & $\begin{array}{l}\text { Spheres, chrome } \\
\text { alloy, composition I. } \\
\text { grade } 50\end{array}$ & $5.5 \mathrm{~h} \mathrm{~nm}$ & 0.42 \\
\hline
\end{tabular}




\section{Experimental Method}

for each material type listed in Tahle 1 , we mesutred anmple permeabrility and porosity as a

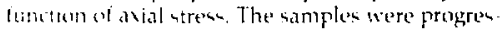

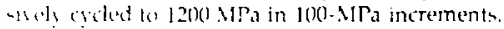
iller tah chles axial stress was released to

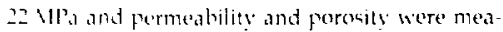
-ured Thin cycling simulated the increase/release of - inem after a nuxlear detonation. The chosen 2 NIra strex walue maximized the ease of die Ilgriment and prese operation. Although a lower

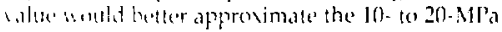

rewitual stress field forming a containment cage around the detonation cavity (Terhune, 1978) ${ }^{2}$ we beljese that measurements made at 22 MPa would not be significantly different irom those determined at 10 to 20 Mira.

Figure 1 shews a schematic diagran of the die ansenbly conlaining the lest sample. The sam. plo is $30.8 \mathrm{~mm}$ in diameter and has an initial

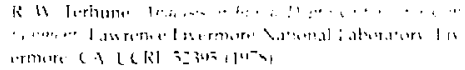

Pressure transclucer

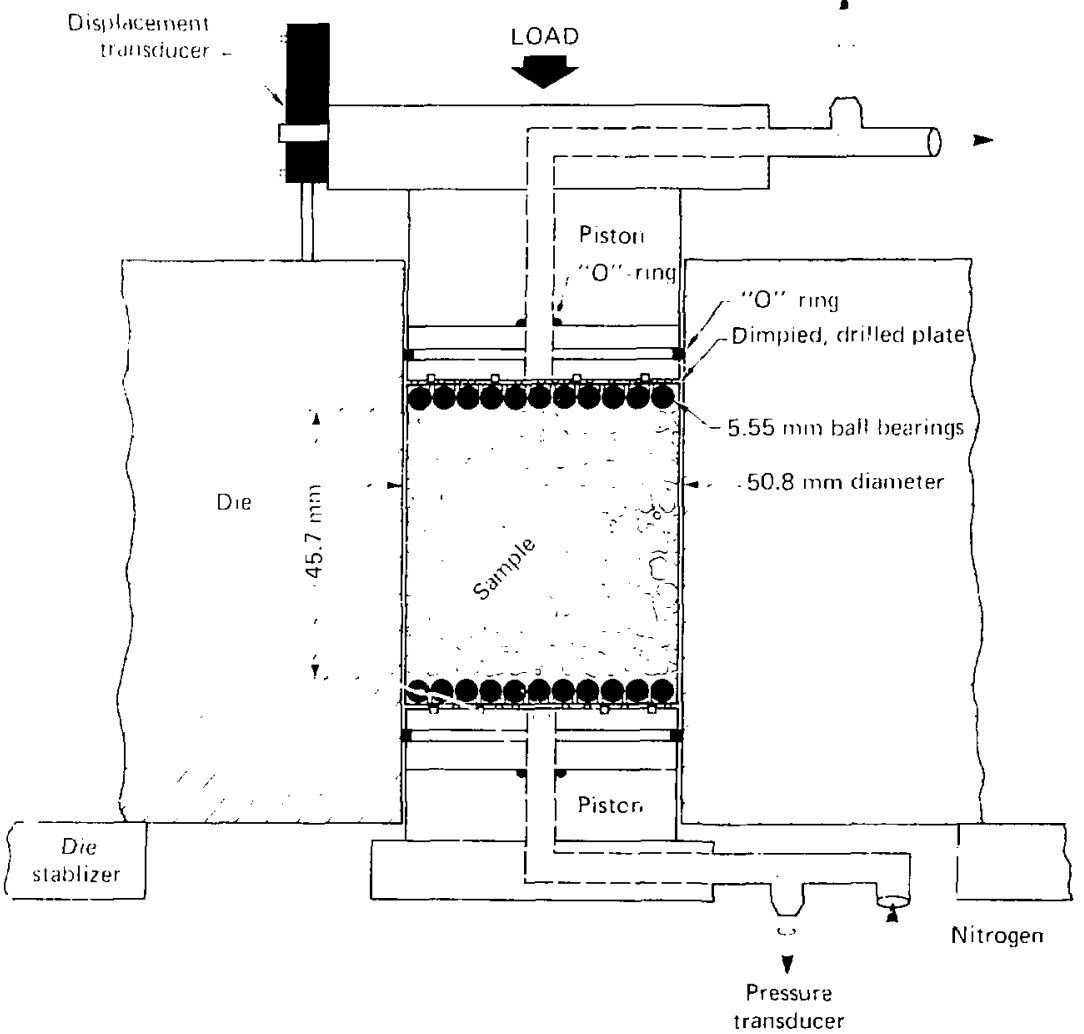

Figure 1. Schematic diagram of pressurc die and sample. 
length of $45.7 \mathrm{~mm}$. The die is terminated at each end with $5.55 \mathrm{~nm}$ steel ball bearings in a dimpled, drilled plate and a slotted piston that has a central orifice (Fig. 2). Axial stress is applied to the top of the sample by a 500 -ton capacity hydraulic press. Figure 3 is a schematic diagram of the plumbing and instrumentation.

lie introduced a flow of nitrogen to the sanple, maintaining the pressure drop across the sam. ple by adjusting the vent value. The mass flow rate, upatream pressure, and average pressure were monitored with mass flow and pressure transducers. All measurements were performed at about $20 \mathrm{C}$. To assure reproducibi' 'y of the data. we measured at leant two samf'e if each of the defferent materials (wecept the -ted osll bearinga).

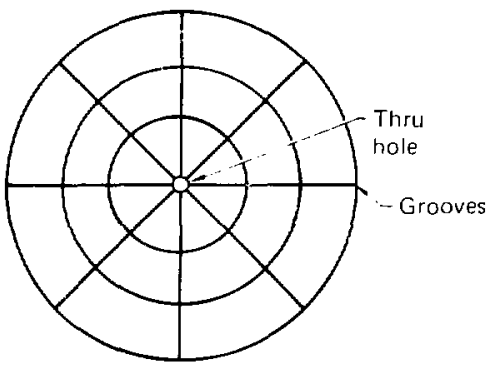

(Plan view)

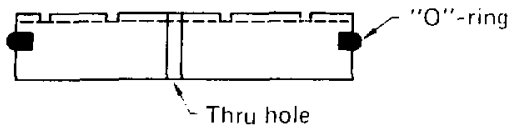

(Cross section)

Piston
Sieasurements at several different flow ratew were recorded after bach stress increment to a sure that the measurements were performed in

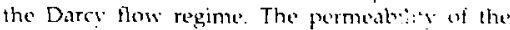
sample to gas is expreased by:

$$
K: \frac{2 \mu 1}{\lambda S \Gamma}
$$

where

$k$ in permesalilits:

(e) in nitrogen flow rate disded by andrage dencits:

$\mu$ is nitrogen sincomits.

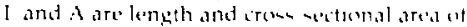
the sample renpertisely and

$-5.55 \mathrm{~mm}$ inimules

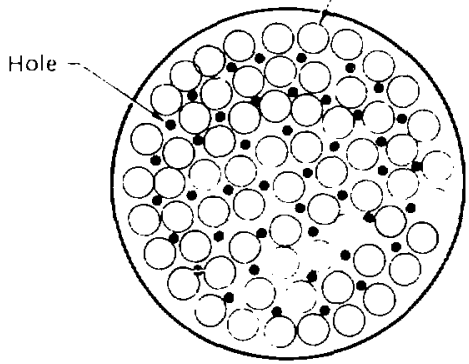

(Ball bearing, sambshls siflel

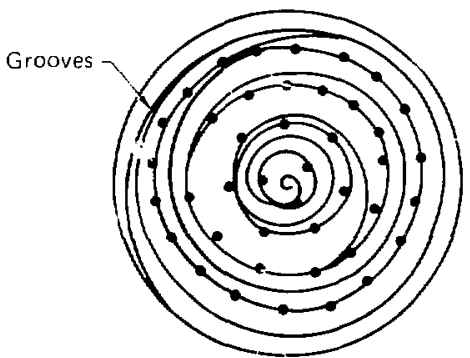

(Piston side)

Dimpled, drilled plaie

Figure 2. Schematic diagram of piston and dimpled, drilled plate. 
$\Delta \Gamma$ in the gas pressure difference hetween the inds of the sample.

Ball bearing distributed the gas over the enthro -ample end and prevented plugging of the holem in the plate with the crushed sample at high strunes. The dimpled torol steel plate supported the baring and the drilled holes distributed the

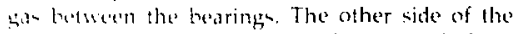
plate wath uromed to colined the gas path from

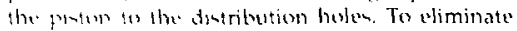

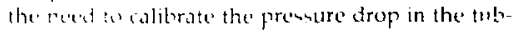
ing wo momtored gat presure with a pressure

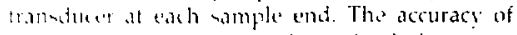
the frematre trandederes determined the maxiinum fermedility that and be measured while the nowros at the flow metere deternined the minimum per:neability. Estimated accuracies for purmeabilities of $2 \times 10^{11} \mathrm{~m}^{2}$ to $4 \times 10^{1 \mathrm{n}} \mathrm{m}^{2}$ (2) to $+\times 2 \mathrm{i})+$ darcies) are $=10^{\circ} \mathrm{n}$

In addition to permeability, the initial length and initial porosity of each material were also measured. Initiai porosity was determined from the weight difference hetween water saturated amplen and dry samples. When the samples are water -aturated. it is assumed that the water fills the intergranular pore apace only: Porosity was determined from the initial porosity, initial sample length, and the change in length during the ex. periment. Initial sample porosity is expressed by:

$\therefore-\frac{a-b}{a b}$

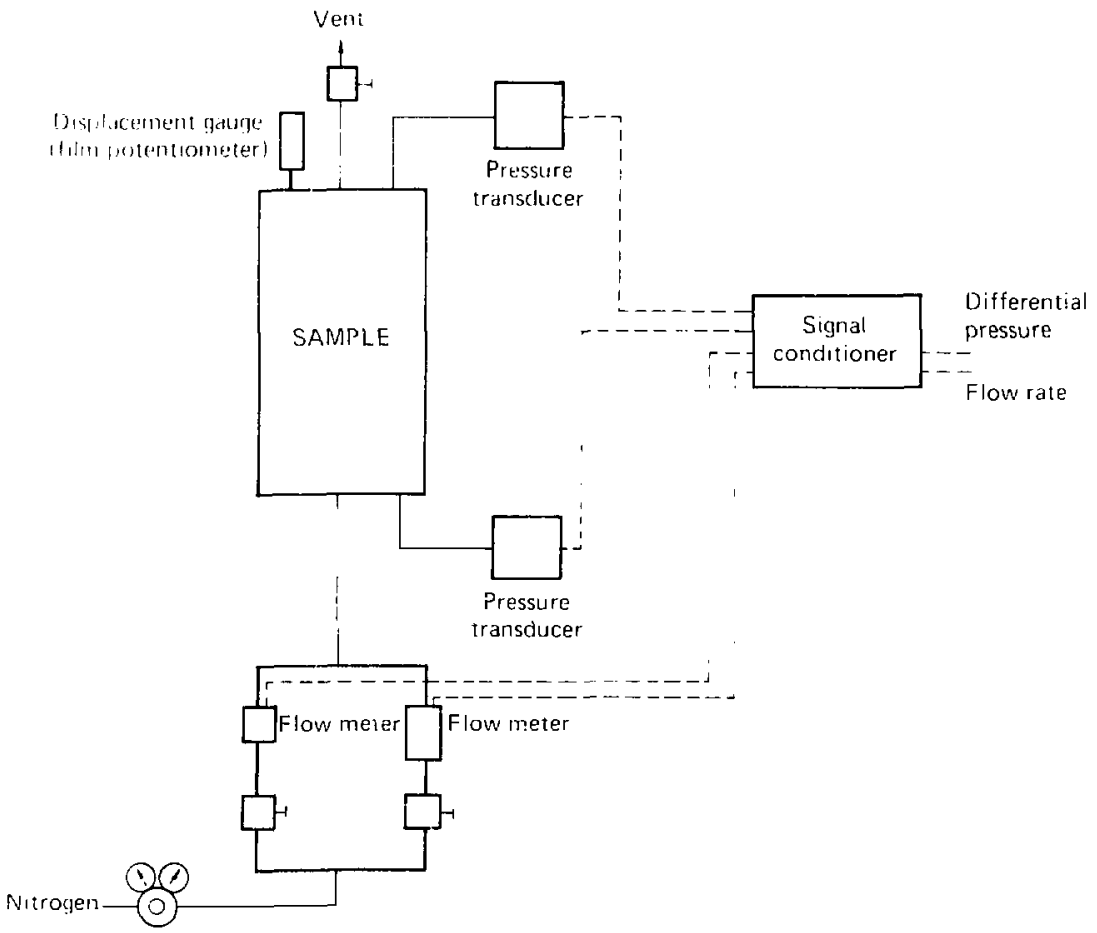

Figure 3. Schematic diagram of plumbing and instrumentation. 
where,

o is porosity:

a is mass of water saturated sample'.

$b$ is mash of the atre simple,

$p$ is the density of water, and

$V$ is the sample volume.

We used a film potentiometer as a diaplacement gange to determine the change in length of the sample. the sample compaction was correded for the sample filling the voids around the ball brarings as the sample was stresest. Since the length measurements were made only at the the piston an error occurs after reltiane if the atren

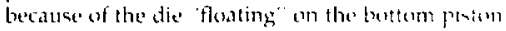
(Fig. 1). Estimated somple length and forromity or

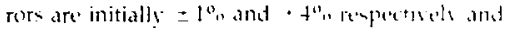

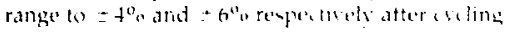
to bight strenste

\section{Results}

We meacured eight different material for permedability and porosits: Figure 4 shoms the permestility of the materials at $22 \mathrm{M}$. strem verus the maximum stress to which the have been aveled Tho fice stemming materials studied appeared to define two group In the

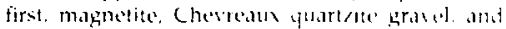

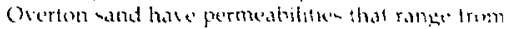

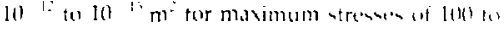

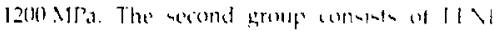

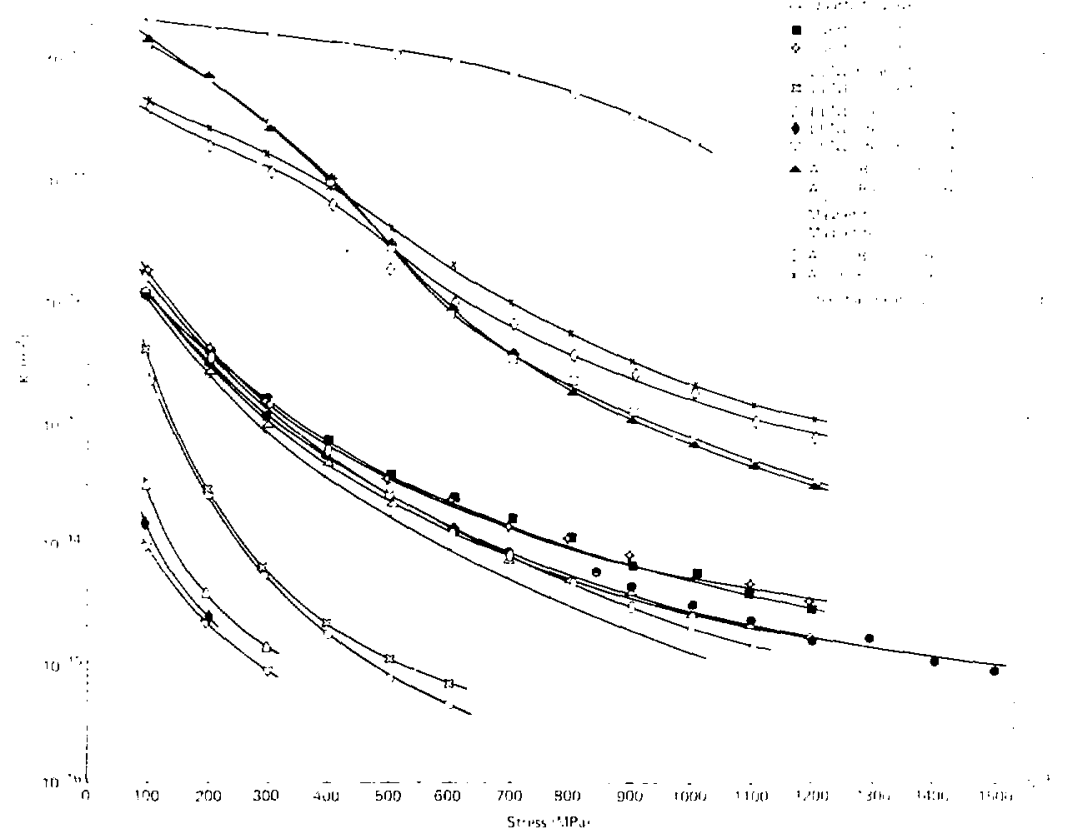

Figure 4. Permeability at 22-MPa stress vs ma imum stress. 


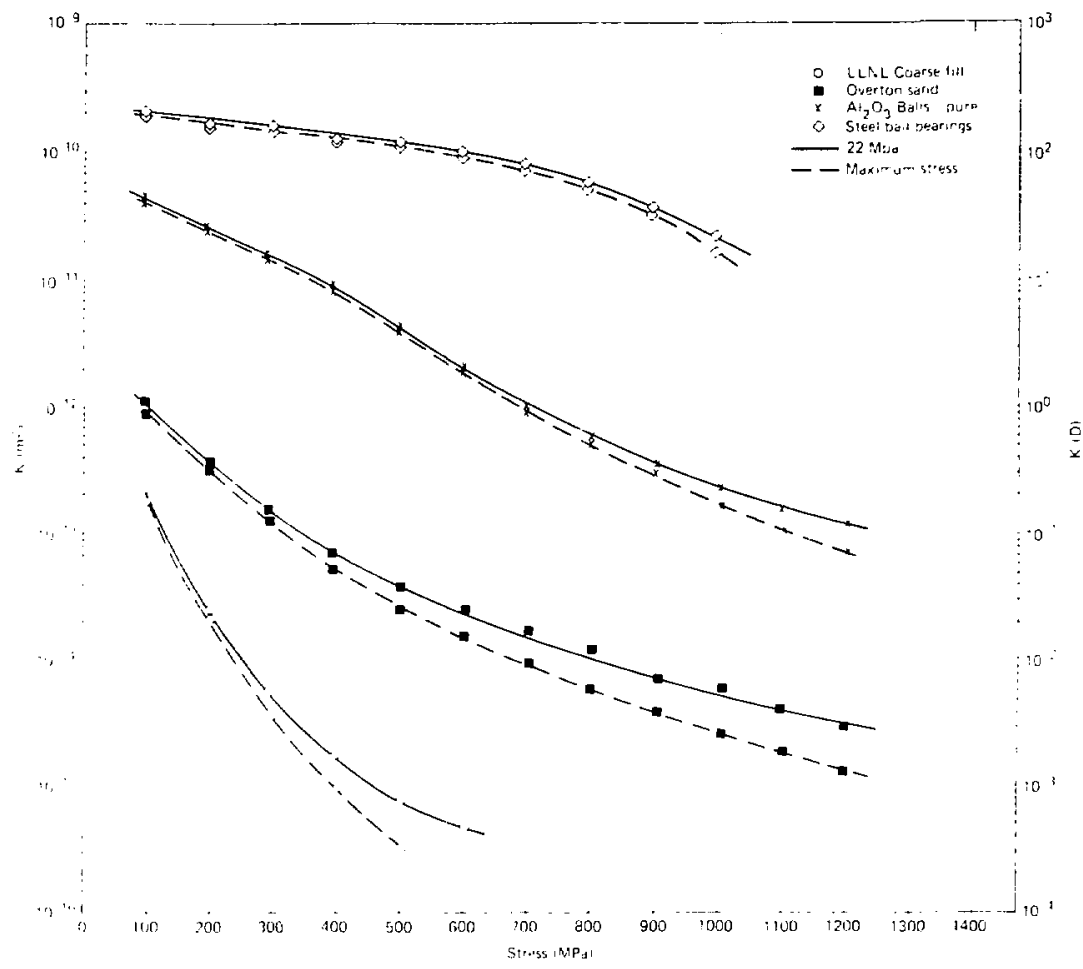

Figure 5. Permeability at 22-MPa stress vs maximum stress and permeability at maximum stress.

"urue fill and I.I.N. itemming nix and are con-iderably hower in permeability: Second-group materialio were not atressed to 1201 Mra since the flow raten weres too small to accurately measure "ermeability I.I.NI coarse fill permeability ranges - :ar 10 . $2010 \mathrm{ll}^{2} \mathrm{~m}^{2}$ for maxinum stresce of : : a $600 \mathrm{~N} / \mathrm{Pa}$ and L.LNL stemming mix perme$\therefore$ : anges from $10^{15}$ to $10^{1 "} \mathrm{~m}^{2}$ for maxi- nesses of 100 to $300 \mathrm{MPa}$. Several man. $\therefore$ raternals were examined as possible alter.... : :rmpt gas sampling application. These - . : : Cumina balls and steel hall bearings. •... . ... far impure and pure alumina $\therefore$. ... : the same and range from $10^{\prime \prime}$ . .. marmum stresses of 100 to
1200 MPa. Permeabilities for stee] ball hearings are substantially higher than all the other materials tested and range from 10 "l" to $10^{11} \mathrm{~m}^{2}$ for maximum stresses of 100 to 1000 MPa. Comparison between duplicate tests on the same materiai indicates that the reproducibility of permeability data for each material at any stress is about $\pm 15^{\circ}$ \%

In Fig. 5, wc compare the permeability behavic, of several materials that are representative of the four groups shown in Fig. 4. The two curves for each material depict the effect on permeability of unloading from the highest stress. In each case. the upper curve, which is identical with the one in Fig. 4, shows the permeability-stress behavior 
when measured at $2291 \Gamma$ after unloading from the maximum tress. The lower curve shows permeatility-heress hefore unloading. Unloading resulted in a 0.5 order of magnitude increase in permeability at the highent stresses. Me bolieve that this increase is coused either by particle rearrangenent or by fractures spening when the sample is unloded. In addition, the dat.s suggest that there is a greater ditlerence in permanability hor the less permeable materials.

Figure o depicts the sample compaction at 22 M Ma strens an a function of the maxinum stress (1) which the sample was creled. The materials with the greatest initial porosity (see Table 1). (")apt the steed ball bearing decreased the most in length. For exampie, li.N. coarse fill decreased $38 \%$ in kongth for mavimum streshes of 0 to (xin) VIra. Alumina and yuartzite gravel decreased

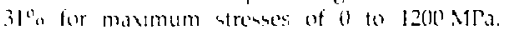
Overton and decrested 290 and magnetite de- ireased $200^{\circ}$ for maximum etressen of 11 th

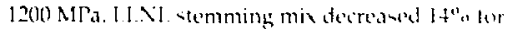

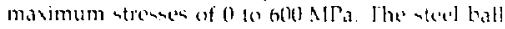

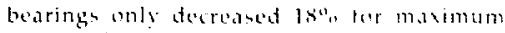

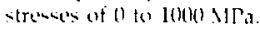

Figure 7 jllustrates porowity at 22 N1ra - trem as a function of the maxumum itrese to which the -ample was cycled. Poresitien for impure alumina range from 0.43 wo 0.18 and quart/lle gravel thom $0 .+3$ to 0.13 for maximum - trenesen al 1 t:

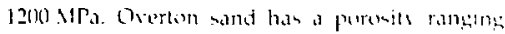

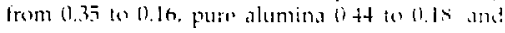
magnelite 11.31 to 01.12 for maximum strenese of 11

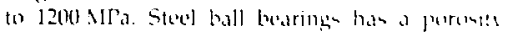

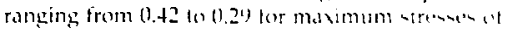

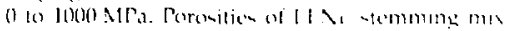

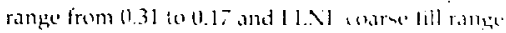
from $0 .+4$ to 0.18 for maximum - tremede is $11 \%$

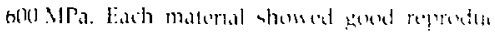
ibilits in porimity. 
$x$

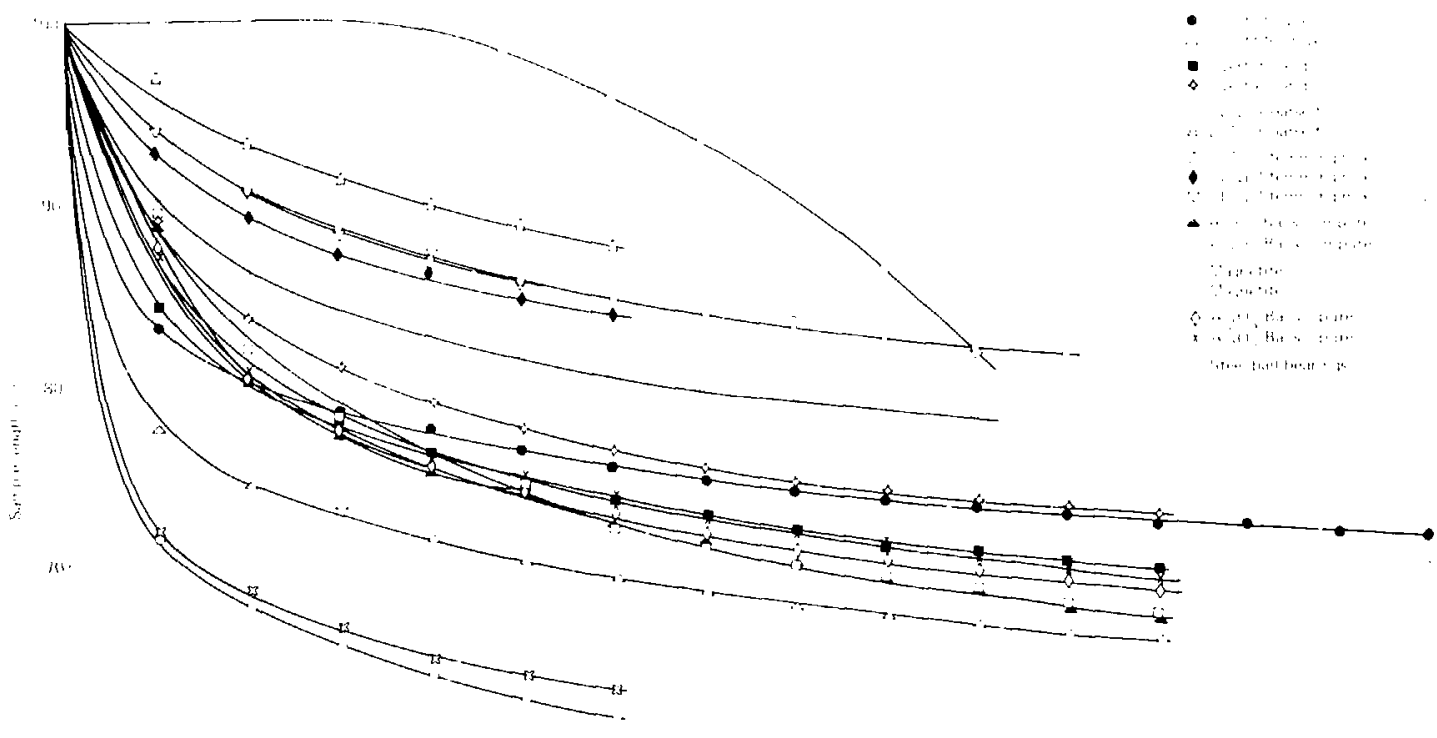

is

Figure 6. Change in length of sample and 22-MPa stress vs maximum stress. 


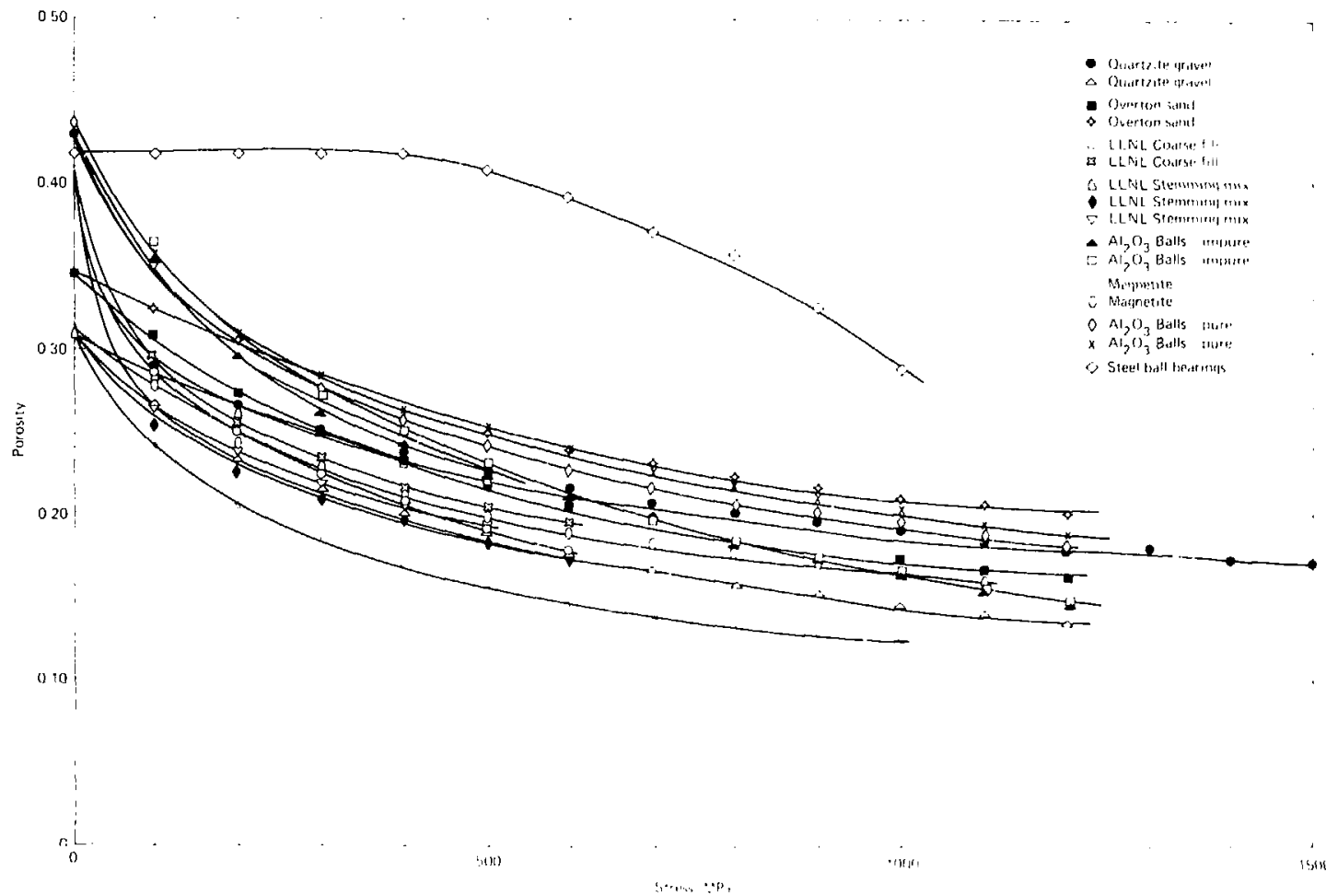

Figure 7. Porosity at 22-MPa stress vs maximum stress. 


\section{Discussion}

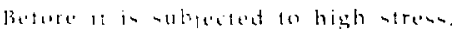

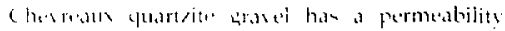
seriter than that of therem and. He have

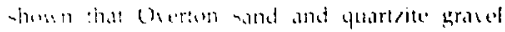

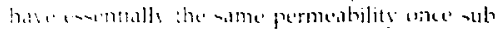

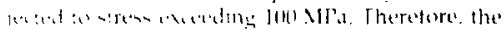

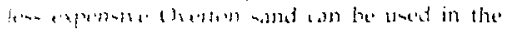

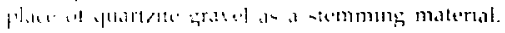

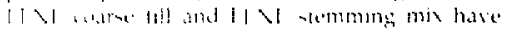

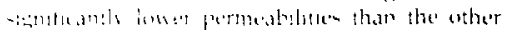

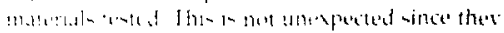

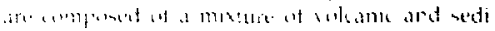

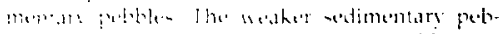

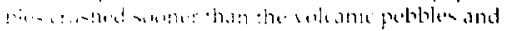

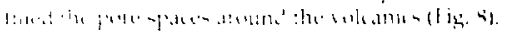

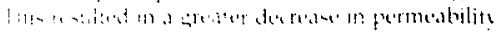

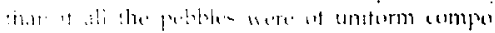

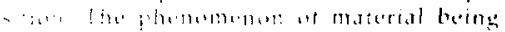

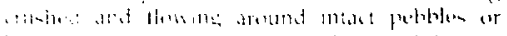

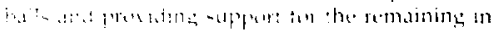

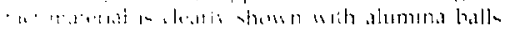

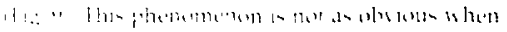

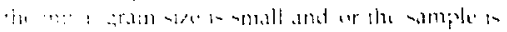

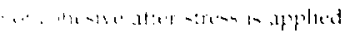

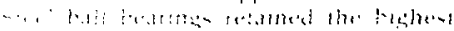

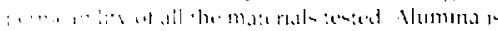

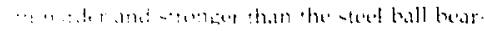

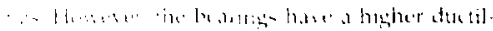

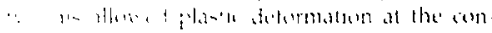

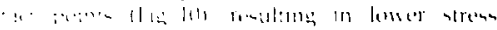

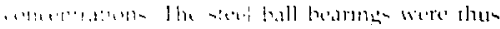

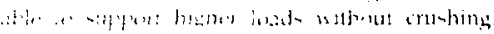

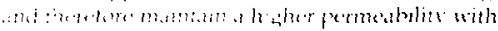
$\because 1,120$

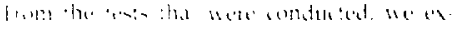

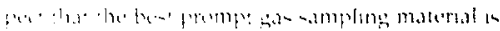
bore

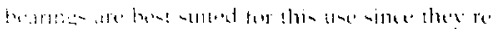

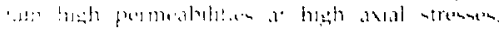

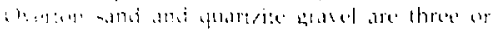

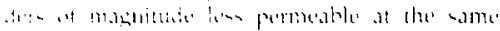

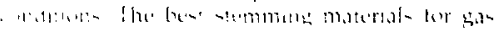

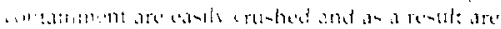

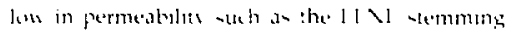
min
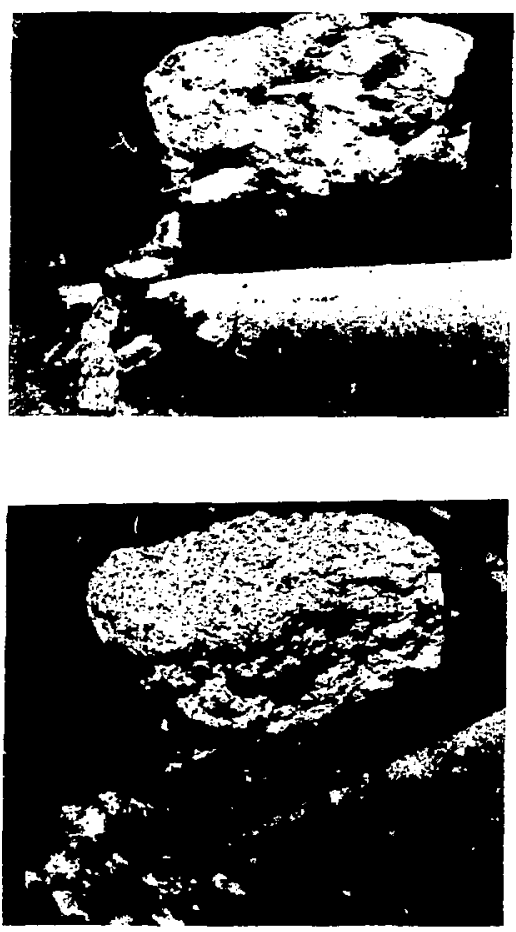

Figure 8. LLNL coarse fill (top) and LLNL stemming mix (bottom) after loading to hOO M1Pa. 
ligure 4. Impure alumina talls (top) and pure alumina balis (bottom) after loading to

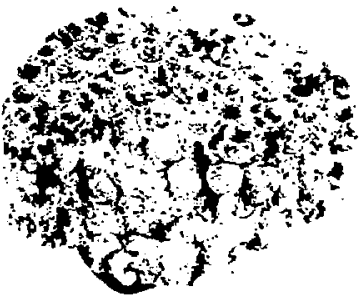
1200 MPa.
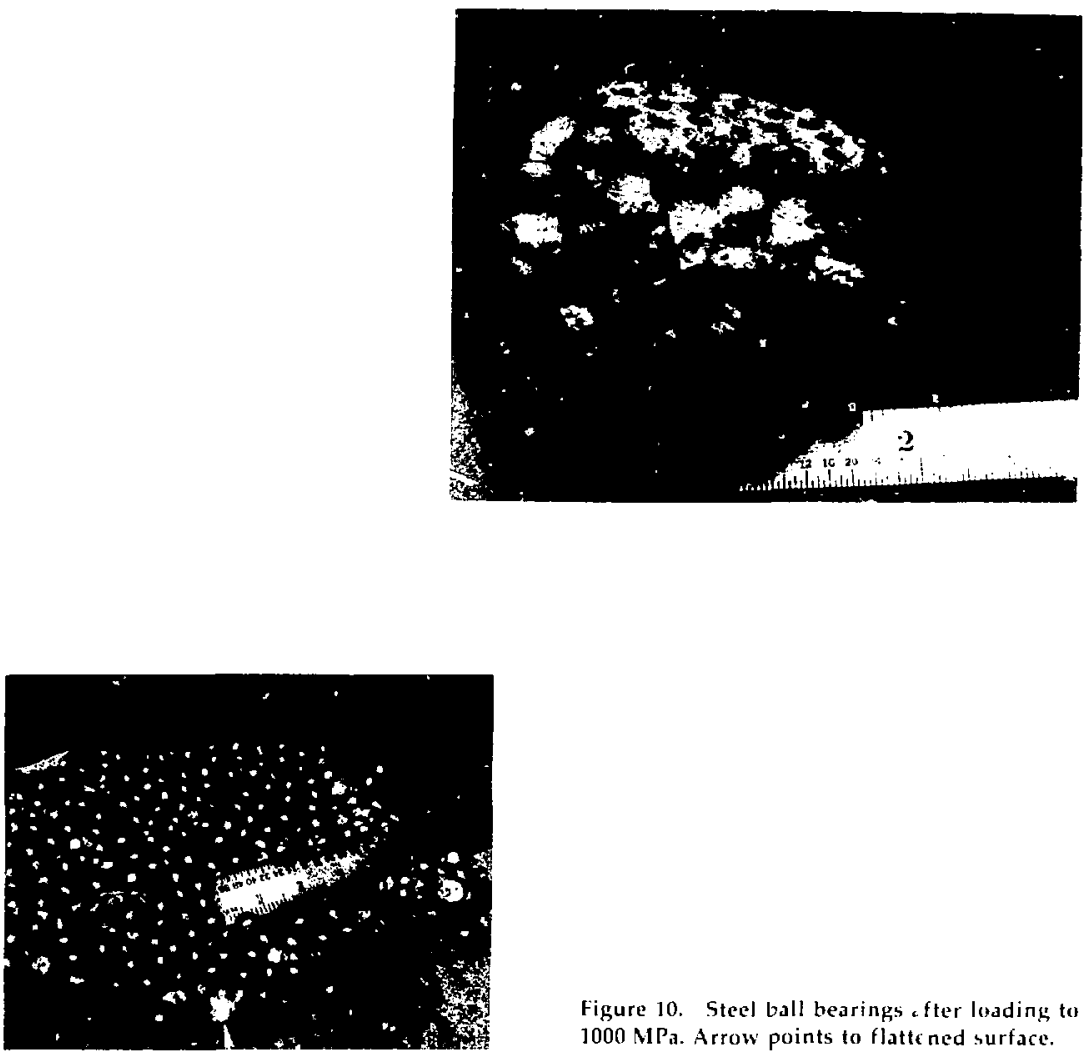

Figure 10. Steel ball bearings cfter loading to $1000 \mathrm{MPa}$. Arrow points to flattic ned surface. 


\section{Summary and Conclusion}

Permeablicy, compartion, and porosity measurements were made on right different materials for stresses to $1200 \mathrm{MPa}$. Stress was increased in $100 \mathrm{MPa}$ increnuents and released to $22 \mathrm{MPa}$ to cimulate the increane/release of stress after a nucledr detonation $m$-iru. Permeability of XIS utemning materials ranged from 10 it $\mathrm{m}^{2}$

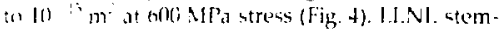
mong mix howed the lowest permeability. Possibue prompt gis samplons materials in lude alumusa halle and steed ball hearings. Pernueability of alamma balle and ated bail bearmers ranged from I1 - In to li 'm at folo Mlla at masimum

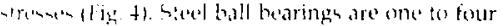
orifore of nolgintude more permedabe than the

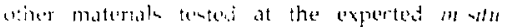
trimen. The etore prompt gals sampling thould ire much entanced by the wie' of heel ball bear. inges in the critical stress region.

These is a general trend in serage poresitan ranging from 0.17 is 0.23 at $600 \mathrm{M}$. ception of the steel ball bearings. The high pernesability materials tend to have high aserage porouilies; while the low permeshilits materials have lus areage poresitien whth the eveption of magnetite. Whather thin trend in meaningtul is hard is determine since there is not a large difereme in finds percesitices

We bediese that the permeatility data in the

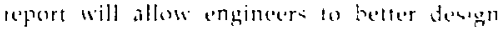
prompt gas ampling yotems. In a'disun the

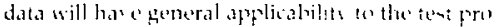

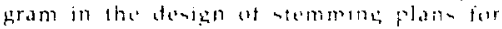
contamment.

\section{Acknowledgments}

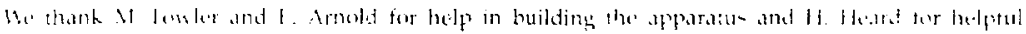

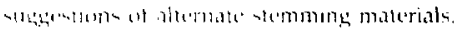

